\title{
Perfecting Rural Land Title for Wealth Creation and Sustainable Development*
}

\author{
${ }^{1}$ D. Asenso-Gyambibi, ${ }^{2}$ M. Affam and ${ }^{1}$ E. Y. Amoafo \\ ${ }^{1}$ CSIR- Building and Road Research Institute, Kumasi \\ ${ }^{2}$ University of Mines and Technology, Tarkwa
}

Asenso-Gyambibi, D., Affam, M, and Amoafo, E.Y. (2019), "Perfecting Rural Land Title for Wealth Creation and

Sustainable Development”, Ghana Mining Journal, Vol. 19, No. 2, pp. 10-16.

\begin{abstract}
Perfecting land title refers to the process of securing tenure on land. It refers to the assurance that the land one holds for an agreed period of time and purpose is certain. It requires a level of legitimacy. It is on record that agriculture, forestry and mining sectors constitute about $70 \%$ of Ghana's gross domestic product. However, the lack of several large-scale plantations in Ghana can be partly attributed to the land tenure system. Land rights in rural communities are not secured in that the lands are not themselves well defined and rights are not documented. The study used modern survey methods to clearly map out farms in a systematic manner for farmers under a cooperative for rubber plantation development. The rights of tenant farmers and landholders are clearly and legally documented and registered into the formal land administration system. The spatial and attribute data are incorporated into a Geographic Information System (GIS) that serves as tool for data management on the farmers. The pilot study was successful in improving not only tenure security and data access, but also access to funding by participating farmers.
\end{abstract}

Keywords: Land Tenure Security, Registration, Spatial Data, Attribute Data

\section{Introduction}

Land tenure is a set of rules that determine how land is used, possessed, leveraged, sold or disposed of within societies. It is the right of individuals and groups of people to effective protection by their governments against forcible eviction (Anon. 2008). Secure rights create incentives for people to improve land management and agricultural production. Secure land is also a common form of collateral for acquiring a bank loan. Research shows that strengthening land tenure often results in improvements in land management, agricultural production and household welfare" (Veit, 2013). While many African countries recognize customary tenure arrangements over land and forests in their national laws, the process of on-the-ground implementation and protection of land right is slow. "Only $10 \%$ of Africa's rural land is registered. The remaining $90 \%$ is undocumented and informally administered- this makes rural land susceptible to land grabbing, expropriation without fair and adequate compensation and result in tenure insecurity" (Anon, 2008). Poor people and disadvantaged groups therefore live in fear of losing their land (Arko-Adjei, 2011). Achieving land tenure reform is by no means an easy or quick process. However, the benefits over the long term can lead to substantial gains for smallholder farmers' competitiveness (Anon, 2008). One major reform that would help farmers across Africa is increased attention to problems of land tenure security (Boudreaux and Sacks, 2009). In Benin, Senegal, Burkina Faso, Madagascar and Niger, the French Development Agency (AFD) started pilot activities in 2012 to promote new perspective on land tenure based on recognition of multiple titles to land, including land use rights and cropping rights (Kabre, 2012). In Francophone countries like Burkina Faso, Benin, Cote d'Ivoire and Rwanda, case studies reveal process of "informal formalization" whereby land transactions are recorded on written documents signed by witnesses and validated by local administrative or customary authorities. These documents usually have little or no legal value because they are often incomplete and unclear as to their full terms and conditions (Lavigne D., 2002; Toulmin et al., 2002). Some African countries have embraced policies abrogating customary systems, as in Eritrea's Land Proclamation of 1994 (Alden, 2003; Anon, 2002). In Tanzania, with the dismantling of traditional rulers at the time of independence in 1961 and in subsequent legislation (e.g. Act No.1 of 1965), the customary land tenure was left to die. The administration of rural lands is entrusted to Village Councils, though the management must be in compliance with the customary law of the respective area (Komu, 2003).

In Ghana, customary rules of land tenure predominate because stools, clans, families and individuals own $80 \%$ of the land with $20 \%$ going for the state (Larbi, 2006). However, most of these lands are not registered. The Land Administration Systems inherited by most African countries including Ghana are formal systems, which involve sophisticated survey and mapping techniques. The key to transforming assets into capital lies in instituting a system of property rights and information on property that is applied nationally and is legible to outsiders (Anon, 2008). The government of Ghana through its Ministries, 
Agencies and Departments has tried to initiate policies, plans, strategies and programmes to improve the overall land administration system in the country (Anon, 2003).

The Ministry of Food and Agriculture (MOFA) in Ghana, with assistance from the German Development Cooperation has instituted an Outgrower and Value Chain Fund (OVCF) to support schemes and integrate small holders into commercial agriculture. The Fund will provide medium to long-term loans (of at least 3 years). The Association of Eastern Region Rubber Out-growers (AERRO) has applied for funding from the Fund through a participating financial institution, called Financial Operator (FO). The project, involving about 1000 farmers, is to establish about 2200 ha of rubber over three (3) years and maintain same for eight (8) years (Anon, 2013). The farmers require the necessary collateral security in the form of land title deeds to back their loans. Unfortunately, the farmers have neither documented titles nor plans. Most of them are only tenants working for the landholders under customary arrangements that have not also been documented.

This study seeks to bring these rural undocumented lands into the formal Land Administration System in the country to improve land tenure security in rural communities. It captures the rights of 475 crop farmers in 12 Districts in the Eastern region of Ghana into the legal framework. The outcome is a secured tenure that ensures security to the farmer as well as landholder and creates an avenue to access capital for sustainable growth and wealth creation.

The objectives of the study are to:

(i) Establish clear unambiguous boundaries of parcels.

(ii) Prepare cadastral plans for each farm through systematic survey and inventory.

(iii) Document and register interests and integrate into the formal Land Administration System.

\section{Resources and Methods Used}

\subsection{Study Area}

The study was conducted in the Eastern region of Ghana (Fig. 1) where rubber plantation development was being promoted with assistance from the German Development agency. The study was piloted in 12 out of the currently demarcated 26 Districts

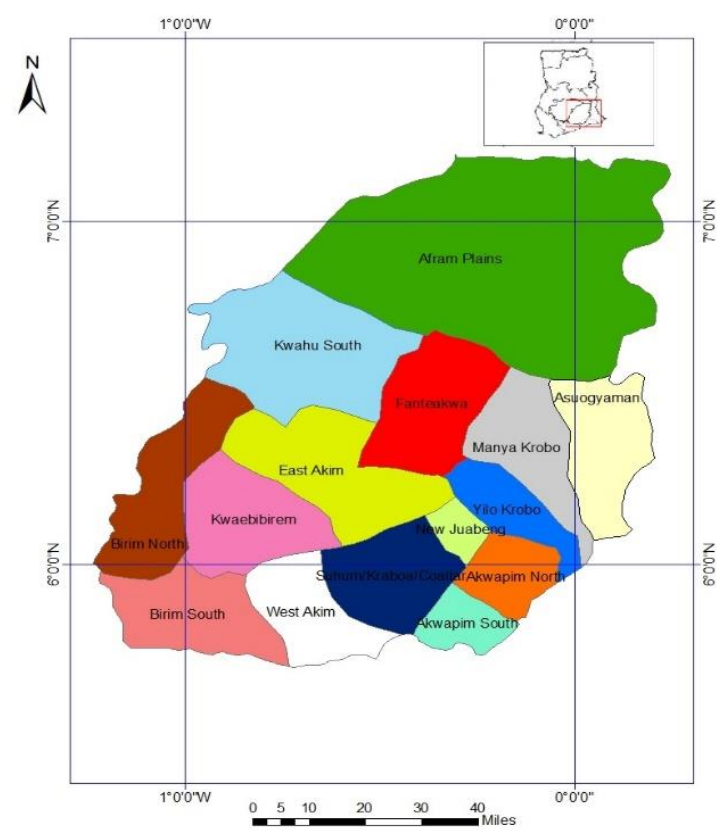

Fig. 1 Map of Eastern Region

The Eastern region has recently been divided into 26 Districts. The Afram Plains and Manya Krobo districts have each been split; Birim Central, Akyemansa and Kwahu East districts have also been created. However, the map for the 26 Districts has not been drawn yet. The region is the third most populated in the country and has a population of 2633154 and land size of 19323sq.km (7461 sq.miles) (Anon, 2010). Table 1 shows the Districts where the pilots for the study with corresponding number of farms.

\subsection{Establishment of Cooperative}

Under a funding arrangement, farmers were brought together to form a cooperative called the Association of Eastern Region Rubber Out growers (AERRO). This group has the legal right to negotiate market prices for rubber produce. AERRO also represented the farmers on funding arrangements. This association was the platform to coordinate with the farmers and landholders. The leaders of this group were made up of people who understood the local customary land issues.

\subsection{Education and Sensitization}

Education and sensitization was carried out for stakeholders to appreciate the benefits of security of tenure to both landholders and farmers. Good governance practices must be followed in land administration if it aims to protect the rights of individuals and enterprises (Zakout et al., 2006). Good governance practices such as participation, transparency, inclusion and equity were employed in this study. 


\subsection{Evaluating Existing Customary Tenure System}

The study was carried out by first evaluating the existing customary land tenure system in the study area through literature review, interviews, interactions with customary owners, the District Assembly and farmers. Through stakeholders' fora, there was education and sensitization to ensure the benefits of improving tenure was acceptable to landholders and tenant farmers. The processes of Alternative Dispute Resolution (ADR) mechanisms in resolving conflicts along boundaries and rights were discussed so that stakeholders understood that there could be better and less antagonistic means of resolving conflicts.

\subsection{Survey of Small holder Farmlands}

Global Position System (GPS) technology was used to capture spatial data relating to farms (Fig. 2). The corners of each farm were surveyed in the presence of owners of adjoining farms. A cadastral plan was prepared for each farm.

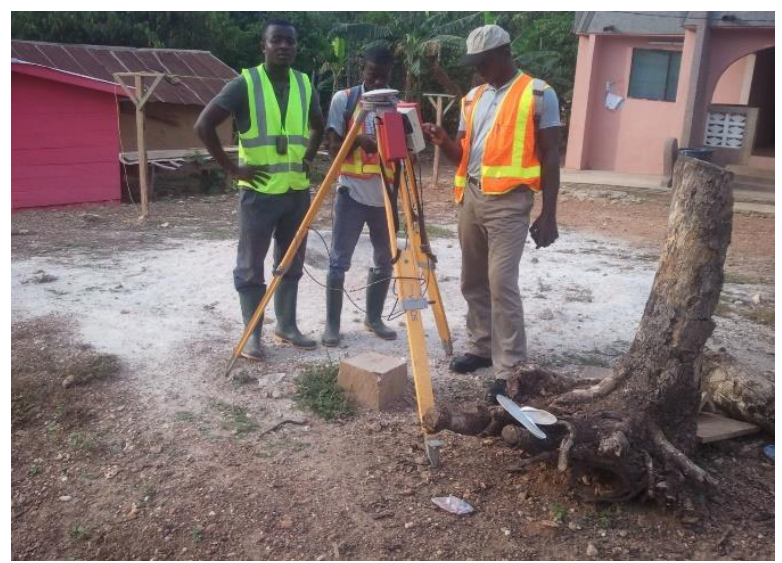

Fig. 2 Surveyors Setting up a Base Station for Systematic Survey of Parcels

\subsection{Administration of Questionnaire}

Questionnaires were administered to 475 farmers to fill with their landholders. This was to capture details of any undocumented agreement between farmer and landholder. From the questionnaires, the primary qualitative data relating to the farmer, landholder, land and tenure were derived.

\section{Development of a Geo-database}

The spatial and qualitative data (also known as attribute data) were linked to create geo-database using Geographic Information System (GIS) software, ArcGIS (Table 2). The geo-database makes information on the rubber plantation, farmer and farm, landholder and customary arrangements readily accessible.

\subsection{Validation Workshop}

From the database, the farmlands and their related attributes could easily be generated. Validation workshops were held for stakeholders (farmers, landholders, traditional authorities, Financial Operator, Rubber Buying company, MOFA officials) to identify with the system. The data had been obtained through the field survey of farms and data derived from the questionnaires. For example, a selected farmland could display attributes such as land size, district in which it is located, name of landholder, name of tenant farmer, gender, educational levels, age, type of tenancy agreement, date of commencement and expiry of tenancy etc.

\subsection{Registration with Lands Commission}

Registration into the formal Land Administration System was undertaken at the Lands Commission. The Lands Commission (LC) played the lead role in ensuring the registration of rights conformed to existing legal framework. Titles were prepared to secure the tenancy at the Lands Commission. Fig. 3 shows the flow chart for the land registration process:

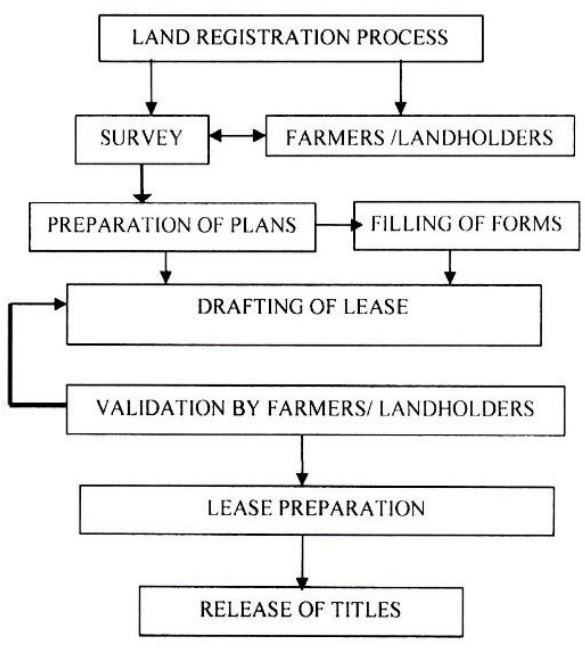

Fig. 3 Land Registration Process

(i) Cadastral plans are prepared in respect of farms.

(ii) Questionnaires are administered to farmers and landowners. The LC legal department drafts tenancy agreements into an acceptable legal framework based on survey and questionnaires.

(iii) Draft leases are brought to AERRO for distribution and validation by farmers and landholders.

(iv) Draft leases come back to LC for final preparation and registration

(v) Errors are corrected (if any), drafts prepared for validation. 


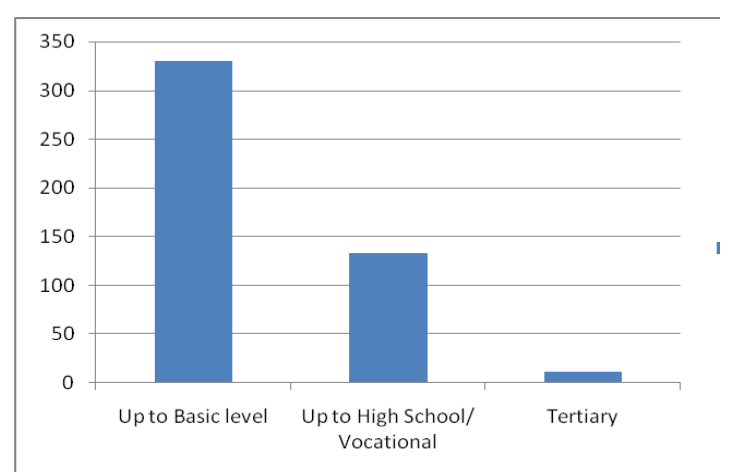

Fig. 6 Farmer Distribution by Education Level

$$
\begin{aligned}
& \text { - Series1, } \\
& \text { Type of } \\
& \text { Tennanc } \\
& \text { y, 0, 0\% }
\end{aligned}
$$

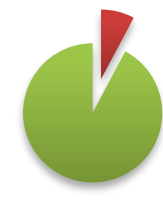

Fig. 7 Tenure/ownership of Farmers

\subsection{Discussion}

The security of tenure is important to funding agencies. It is the surest way for fund managers to secure loans and improve access. Without security of tenure, it will be difficult for the farmers to access capital, especially when their rights in the land cannot be ascertained by way of plans and documents.

In Africa, agriculture employs significant number of rural youth. However, this study shows the youth formed just $4.42 \%$ though $52.84 \%$ were below 40 years. It was also observed from the study that a high number had education up to basic level (69\%). Unfortunately, agriculture is not a major subject in the curriculum at the basic level in Ghana. The relatively larger land sizes in this study belonged to people, most of whom stayed in urban areas and gave out land on tenancy. Low number of women were involved in the plantation. Only $8 \%$ of the farmers owned or held allodial ownership rights to the land. A total of 1541acres (623.93ha) of rubber is under cultivation in this project, with prospects of expansion to other Districts and regions in Ghana. Extension of credit and technical services to farmers will boost production and encourage the youth to get involved to ensure sustainability.

The geo-database is a useful tool that helps AERRO to keep track of its members. The Financial Operator is in a better position to monitor, evaluate and extend assistance to the farmers because of the geodatabase.
Based on the accurate farm sizes, the Operator knows the limit of financial assistance to extend to the farmer. The extension officers at MOFA can use the system to track farmers and offer assistance without necessarily travelling to the field personally. This is because they have all relevant data about the farmers and their farms "on their desk" in the office. For example, the extension officers know the number of seedlings or fertilizer to supply a farmer based on the accurate farm size.

Accessibility to farms: Accessibility to some farmlands was a challenge due to bad roads. In some instances, the survey team had to walk long distances with their instruments and pillars to carry out demarcation of farms.

Institutional Bureaucracy: The bureaucracy at the Lands Commission continues to be a drawback. Officers, due to parochial interests create unnecessary delays. Innovations and reforms are not easily carried through by the state land administration agency.

Inconsistent Information: Some farmers and landholders provided different information at various times. For example, a farmer will provide a name other than that which is on his valid identity card. Landholders and farmers always exaggerated the farm sizes, but the scientific survey always corrected such information by way of the plans produced.

Education Level of Farmers and Landholders: The low educational level of most farmers was also a challenge and a lot of education had to take place in this study. People had to be recruited to assist in answering questionnaires. This increased the cost of the study.

\section{Conclusion and Recommendation}

\subsection{Conclusion}

Systematic survey through the cooperative arrangement is a good practice that helps promote inclusiveness in land administration at the local level. When rural land tenure systems are effectively integrated into the formal land administration system, it provides adequate tenure security and promotes investor confidence. Agricultural productivity and growth are sustained, and wealth is created. The application of modern survey methods is important in getting boundaries clearly demarcated. Introduction of modern technology like Geographic Information System (GIS) as in this study helps make data easily accessible. 


\subsection{Recommendation}

Institutional reforms are recommended to facilitate rural customary tenure into the land administration system to protect rights of the vulnerable, women and farmers who do not own lands or have no land rights. Government must encourage cooperatives that can ensure the rights of farmers are protected. Capacity building at the District level is recommended so that land administration is decentralized. Survey rules and specifications must be amended to make room for the use of simple but modern technologies such as handheld GPS, drones and Real Time Kinematic (RTK) GPS for farm surveys in order to reduce cost of survey. Large scale systematic surveys and Rural Parcel Right Demarcation (RPRD) for plantation development is highly recommended to enhance and sustain agricultural productivity in Ghana

\section{Acknowledgement}

The German Development Cooperation through the National Investment Bank (NIB) of Ghana financed the project. The Out grower and Value Chain Fund (OVCF) of the Ministry of Food and Agriculture (MOFA), Ghana, played a coordinating role. The Association of Eastern Region Rubber Out grower (AERRO) was the cooperative organization that brought farmers together and played a facilitating role in education and sensitization. The Rubber Plantation Ghana Limited (RPGL) was the rubber purchasing company that provided technical services to farmers and provided the kind of attributes required to make the geo-database effective.

\section{References}

Alden, W. L., (2003), "Governance and Land Relations: A Review of Decentralization of Land Administration and Management in Africa", International Institute for Environment and Development, London, 98 pp.

Anon. (2002), "Law and Sustainable Development since Rio: Legal trends in agriculture and natural resource management", Rome, FAO, Legislative study, No 73. www.fao.org, Accessed: June 13, 2012.

Anon (2003), "Project Appraisal Document, Land Administration Project (LAP-1)", Ministry of Lands and Forestry, Accra. www.ghanalap.gov.gh, Accessed: June 3, 2011

Anon. (2007), United Nations Human Settlement Program, Enhancing Urban safety and Security: Global Report on Human settlements 2007, Abridged, http://www.unhabitat.org/download/docs/GRHS.2007. Abridged. Vol.2.pdf, Accessed: June 10, 2015.
Anon. (2008), “Agriculture for Development". Washington D.C., http://www.intersources.worlbank.org/INTWDR2008/Resources/WDRoo _book.pdf.139, Accessed: May 10, 2010.

Anon (2010), "Ghana Statistical Service. Population and Housing Census. Final Results", www.statsghana.gov.gh>pop_stats, Accessed: December 13, 2012.

Anon. (2013), "Project Document: Perfection of Land Title Deeds for Rubber Out grower Farms in The Eastern Region of Ghana", Rubber Plantation Ghana Limited (RPGL) and Association of Eastern Region Rubber Outgrowers (AERRO), Kade. 78 pp.

Arko-Adjei, A. (2011), “Adapting land administration to the institutional framework of customary tenure, Case of Peri-Urban Ghana", $\mathrm{PhD}$ thesis, Delft University of Technology, Sustainable Urban Areas Vol. 39, 284 pp.

Boudreaux, K. and Sachs, D. (2009), "Land Tenure Security and Agricultural Productivity", George Mason University, Mercatus on Policy no. 57, pp 1-100

Kabre, P. (2012), "Land tenure issues and challenges, Perspectives on land tenure in Africa, Agence Francais de development, ideas4development .org. Accessed: December 12, 2016.

Komu, F. (2003), "Customary Land Tenure System in Tanzania", $4^{\text {th }}$ AFRES Conference, University of Nairobi, March 12-13, pp.11

Larbi, W.O. (2006), "Land Administration Reform in a Plural Environment, Case Study of Ghana", http://www.fig.net/pub/accra/papers/ps01_02_l arbi.pdf, Accessed: September 12, 2015

Lavigne, D.P. (2002), "When farmers use pieces of paper to record their Land Transactions in Francophone Rural Africa: Insights into the Dynamics of Institutional Innovation in $\mathrm{T}$. Benjaminsen and C. Lund, Securing Land Rights in Africa, London", Frank Cass. pp. 89-108.

Toulmin, C. Lavigne Delville, P. and Traore, S. (ed.) (2002), "The Dynamics of Resource Tenure in West Africa", IIED/ James Currey/ Heinemann, London/ Oxford/ Portsmouth (N.H.). 242pp.

Viet, P. (2013), "Shedding light on land tenure in Africa”, www.wri.org, Accessed: May 10, 2015. Zakout, W., Wehrmann, B. and Torhonen, M. (2006), "Good Governance in Land Administration: Principles and Good Practice", The World Bank, $F A O$, Washington, D.C., 20 pp.

\section{Authors}

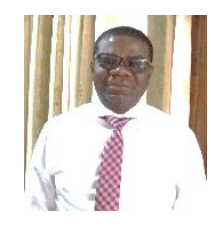

Daniel Asenso-Gyambibi is a Principal. Research Scientist with the CSIR-Building and Road Research Institute. He holds both MPhil and BSc degrees in Geomatic Engineering from University of Science and Technology, Kumasi. His areas of interests are Geographic Information System Land Administration, Survey and Mapping. He has worked on a number of projects in the country. 


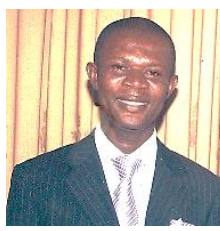

Michael Affam is currently an associate professor in the Department of Geological Engineering, University of Mines and Technology (UMaT), Tarkwa, Ghana. He holds $\mathrm{PhD}$ degree in Geological Engineering (Geotechnical option) from UMaT/ Queens University, Canada, MSc and BSc degrees from Kwame Nkrumah University of Science and Technology, Kumasi. Ghana. His specialty is in applied geomechanics, foundation design and exploration techniques

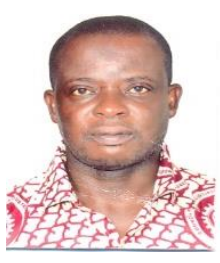

E.Y Amoafo is a Research Scientist at the Council for Scientific and Industrial Research Institute-Building and Road Research Institute. He holds Msc. in Road and Transportation Engineering, Bsc. in Geomatic Engineering and Diploma in Mine Survey all from Kwame Nkrumah University of Science and Technology (KNUST), Kumasi. His interest is in survey and mapping for land use and land administration and engineering survey. 